\title{
NARRATIVES AS APPROACH TO INTERPRETER IDENTITY
}

\author{
Werner L. Heidermann 1 \\ Markus J. Weininger 1 \\ 1Universidade Federal de Santa Catarina, Florianópolis, Santa Catarina, Brasil
}

\begin{abstract}
Translator and interpreter identity came into focus with the "cultural turn" in the first decade of the new millennium (Pym 2004) and even more in the 2010s with the "sociological turn" in translation and interpreting studies (Wolf 2012). In this paper we explore narratives as an approach to understanding complex and not rarely conflictive interpreter identities in two ways. In a theoretical sense we understand that interpreting is to process, adapt and reconstruct narratives in a cognitive way that is compatible with, accessible and acceptable for all parties involved, based on Humboldt (1999), Wittgenstein (1922), Eco (1986), Blikstein (1997), and others as well as on Baker (2006) who describes the world as a projection of conflicting narratives that are the same time the very reason for the need for interpreting and for identity conflicts of interpreters. On the other hand, we look at literary narratives about interpreters or written by interpreters to illustrate the findings of the first part of this article.
\end{abstract}

Keywords: Narratives; Translation and Conflict; Intercultural Identity; Interpreter Identity

\section{NARRATIVAS COMO ABORDAGEM À IDENTIDADE DE INTÉRPRETES}

Resumo: A identidade de tradutor e intérprete entrou em foco com a "virada cultural" na primeira década do novo milênio (Pym 2004) e ainda mais na década de 2010 com a "virada sociológica" nos estudos da tradução e interpretação (Wolf 2012). Neste artigo, exploramos de duas maneiras narrativas como uma abordagem para compreender a identidade 
complexa de intérpretes, não raramente conflitiva. No sentido teórico, entendemos que interpretar é processar, adaptar e reconstruir narrativas de uma forma cognitiva que seja compatível, acessível e aceitável para todas as partes envolvidas, com base em Humboldt (1999), Wittgenstein (1922), Eco (1986), Blikstein (1997) e outros, assim como Baker (2006), que descreve o mundo como uma projeção de narrativas conflitantes que são, ao mesmo tempo, a própria razão para a necessidade de interpretação e para conflitos de identidade de intérpretes. Por outro lado, analisamos narrativas literárias sobre intérpretes ou escritas por intérpretes para ilustrar as descobertas da primeira parte deste artigo.

Palavras-chave: Narrativas; Tradução e Conflito; Identidade Intercultural; Identidade de intérpretes

\section{What is interpreting?}

Fifty years ago, Reiss (xii) states in her introduction to translation criticism that the ever-growing exchange of information in the modern world makes communication itself impossible without translation in its oral and written forms. Schleiermacher "On the different methods of translating" differentiates between the highly valued translation of works of art and science and mere interpreting of technical, commercial or everyday negotiations and for a long time the frontier between translating and interpreting was related to the written or oral channel. Baker (Routledge encyclopedia 40) almost two hundred years later still states interpreting as "the oral translation of the oral discourse". Jones (5) defines interpreting as "immediate oral translation". De Groot (456) follows this line: "the modes of input and output are visual and written mode in the case of translation and auditory and verbal mode in the case of interpreting". Farahani and Farahani add another criterium: "Unlike translation, which refers to the written output based on a written input, interpretation refers to the oral output based on oral input (impromptu) or written input (sight interpreting)." Sign language translation/interpreting shows clearly that the written or oral input or output are not sufficient as criteria for a consistent differentiation between the two translational activities as both 
translation (normally from a written input) and interpretation (in general from a spoken input) in this case use the same modality of sign language as output. But even without signing involved, the definitions are incomplete as there are also forms of interpreting with written output (e.g., real-time subtitling in audiovisual contexts). Weininger (87) gives additional criteria for the

[...] nature of interpreting whose specificity in opposition to translation is not only the temporal proximity between source text input and target text output or the specific mode. What differentiates the two activities is that in interpreting the first version is the definitive one, without the possibility of editing, improving, revising or correcting, without the option of consulting dictionaries, parallel texts or other auxiliary resources. ${ }^{1}$

Nolan (3) transmits a similar point of view:

The translator relies mainly on thorough research with background materials and dictionaries in order to produce the most accurate and readable written translation possible. The interpreter relies mainly on the ability to get the gist of the message across to the target audience on the spot. [...] The translator's activity is more like that of a writer, while the interpreter's performance is more like that of an actor. A good translator will spend much time searching for the correct technical term or the right choice of words, but a good interpreter must immediately come up with a satisfactory paraphrase or a rough equivalent if le mot juste does not come to mind, in order not to keep the audience waiting.

${ }^{1}$ Our translation. 
We will come back to the implications of Nolan's metaphor of interpreters as actors who put forward adjusted personae to allow for linguistic and cultural mediation between the involved parties.

\section{Semiotics \& language philosophy}

Semiotics and philosophy of language help to deepen the due analysis of structure and characteristics of the raw material of interpretation, as well as to comprehend the genesis and elaboration process of its final product. Stecconi (16) claims that despite the obvious connection and various calls for a translation specific semiotic theory, there is no such thing until today. Nevertheless, semiotics and language philosophy provide plenty of material for deepening the view on the subject of translation semiotics.

Even at the risk that it might seem a bit far-fetched at a first glance, we will initiate this theoretical investigation about interpreter identity with Wilhelm v. Humboldt. Marko Pajević who teaches at the University of Tartu (Estonia), renowned for its contributions to Cultural Semiotics and Translation Studies (for example, by Yuri Lotman who created the concept of 'semiosphere', and his successor, Peeter Torop who defends in "Total'nyı̆ Perevod" that translation is to be seen in a much broader way and suggests detailed translation strategies based on that idea) studies Humboldt's writings and declares (Pajević, Thinking language 1):

It was almost 200 years ago that Wilhelm von Humboldt developed his ideas about what language is and does; since then, the dominant linguistic movements of the Anglophone world have given little consideration to his writings. Even though his work is often referred to on a superficial level, the reception of his writings in the Anglophone world is at best partial and certainly problematic. There is, however, good reason to believe that his time is yet to come.

Cad. Trad., Florianópolis, v. 39, no 3, p. 50-89, set-dez, 2019. 
According to Pajević (Thinking language 4) the area most influenced by Humboldt's ideas is the field of Translation Studies, citing a list of famous names indebted to Humboldt such as George Steiner, Henri Meschonnic, Antoine Berman, Jacques Derrida, Lawrence Venuti, among others. One of the pillars for this claim is Humboldt's description of language as a process, not a product (energeia vs ergon) that anticipates at the same time Derrida's crusade against logocentrism and Berman's quest for preserving alterity in translation as well as Meschonnic's idea that translating is impossible without a complete theory of language and society. "Car il suffit d'une traduction, il suffit d'une phrase, pour vérifier que le traduire suppose toute la théorie du langage. La théorie du langage e la traduction se situent l'une par l'autre, ont besoin l'une de l'autre" (Meschonnic 200-201). This is due to the fact that, according to Humboldt, language is not just a system that transports meaning from one user to another. Language is in the first place a means of perception for Humboldt; without linguistically construed and organised labels our sensorial perception is "blind". We need linguistic concepts and schemes to be able to reproduce the outside world in a mental representation that at the same time allows us to interact with "world" and "self". In the second place, language is the "organ" that forms thought, cognition, i.e., the processing of perceptions ("Die Sprache ist das bildende Organ des Gedanken”).

Language is the formative organ of thought. Intellectual activity, entirely mental, entirely internal, and to some extent passing without trace, becomes, through sound, externalized in speech and perceptible to the senses. Thought and language are therefore one and inseparable from each other ${ }^{2}$.

${ }^{2}$ Humboldt (51); see Trabant on the cognitive function of language and the dialogical conception of thought in Humboldt's view and Grewendorf (180ff) on modular theories of mind with mutually interdependent subsystems.

Cad. Trad., Florianópolis, v. 39, no 3, p. 50-89, set-dez, 2019. 
This implies, among other aspects, that the instrument and the object of analysis in the field of language philosophy and linguistic analysis coincide. Last but not least, language is a way to communicate to others the results of processing our perceptions. Through the dialogical construction of thought among individuals meaning is generated and negotiated, composing language as a social entity to which individuals contribute and by which they are influenced and constituted.

In language, humans create their worldview (the famous Humboldtian term of Weltansicht) each time anew, and they do so in speech, together with an addressee who reflects their speech, and this addressee as an outward reality gives it objectivity and validity. Language in the last instance creates the common articulated world. ${ }^{3}$

This peculiar and intricate complexity of multiple, reciprocally intertwined poiesis has far-reaching implications. One of them is pointed out by Humboldt (64) as follows:

Only in the individual does language receive its ultimate determinacy. Nobody means by a word precisely and exactly what his neighbour does, and the difference, be it ever so small, vibrates, like a ripple in water, throughout the entire language. Thus, all understanding is always at the same time a not-understanding, all concurrence in thought and feeling at the same time a divergence. The manner in which language is modified in every individual discloses, in contrast to its previously expounded power, a dominion of man over it.

This perception of the (contextual) relativity of meaning and the conditions of understanding clearly relates to more recent theories

${ }^{3}$ Pajević (Humboldt's Thinking Language 102) 
in the field of Translation Studies. If there is no such thing as a fixed meaning even within one and the same language, this automatically implies the impossibility of establishing simple equivalences in translational situations. It precedes deconstructivism with its view that any text ultimately has as many meanings as readers.

Further on in the same text Humboldt analyzes the relation between the individual and collective level of language use, at the same time tying it up to the formation of nations and national character (Humboldt 34-50) and the individual manifestation of it in any concrete language use. On page 42 he states:

So although languages are thus the work of nations, in a sense of the term liberated from all misunderstanding, they still remain the self-creations of individuals, in that they can be produced solely in each individual, but only in such fashion that each presupposes the understanding of all, and all fulfil this expectation. Though we may now consider language as a world-view, or as a linkage of thoughts, since both these tendencies are united within it, it still always necessarily rests upon the collective power of man; nothing can be excluded from it, since it embraces everything.

On the one hand, this argument speaks in favour of linguistic relativism: "Since language, in whatever shape we may receive it, is always the mental exhalation of a nationally individual life, both factors must also enter there as well" (Humboldt 47). On the other hand, it is the universal condition of language and mankind as such. We cannot escape language. The paradox of a "nationally individual life" points at a conceptual continuum along the microand macro-dimensions of language and human existence.

Wittgenstein in his Tractatus Logico-Philosophicus ${ }^{4}$ enters Humboldt's paradox of meaning from the opposite direction,

${ }^{4}$ We use C. K. Ogden's translation. There are useful hypertext editions of this translation that give simultaneously access to the German text of the Tractatus, e.g., < http://tractatus-online.appspot.com/Tractatus/ jonathan/index.html >. 
analysing the absolute condition of language, knowledge and thought, in the words of Phillips (144):

Wittgenstein's approach, as we have seen, is therapeutic
in function: its task is the clarification of the possibility
of having a meaningful language and picture of the world.
Specifically, Wittgenstein attempts to lay out the logical and
extralinguistic limits and the pertinent rules for language use
so that meaning and its means of constellation are disclosed.

In opposition to Humboldt, Wittgenstein (Tractatus 3.1) declares: "In a proposition a thought finds an expression that can be perceived by the senses." In other words, thought precedes language. Ultimately for the early Wittgenstein of the Tractatus, language is to be found in the world itself that is the basis for all propositions and not a dialogical creation as in Humboldt (Tractatus 1.1): "The world is the totality of facts, not of things" facts here can be read as absolute entities as opposed to things that are representations. Nevertheless, the expression of thoughts permits that thinking is turned into an object that can be perceived (and communicated) as for Humboldt. Phillips argues that later, in his Philosophical Investigations, Wittgenstein shifted his focus towards the empirical and pragmatic dimension of language.

But even within the idealistic conception of pure and absolute language, Wittgenstein states in the context of defining the truth conditions of propositions that "The limits of my language mean the limits of my world" (Tractatus, 5.6). In Tractatus 5.62 this is described as solipsism: "That the world is my world, shows itself in the fact that the limits of the language (the language which I understand) mean the limits of my world." And Tractatus 5.64 concludes: "The I in solipsism shrinks to an extensionless point and there remains the reality co-ordinated with it". In other words, we are imprisoned by the propositions our language allows us to compose. This absolute limitation of propositions about world gains 
relativity at the very moment we think of different subjects and even more so, different languages, even if this was not Wittgenstein's primary scope ${ }^{5}$.

The so-called Sapir-Whorf-Hypothesis (cf. Sapir, and Whorf), developed in the 1930-ies on the basis of ethnographic field studies of native North American languages, which states that the specific language we speak determines our worldview is at the same time based on Humboldt and Wittgenstein and was heavily discussed, for instance by Gipper (Gibt es ein sprachliches 79-80) who defends that if language was such a rigid prison, Whorf himself would not have been able to perceive and describe the relation that later carried his and his teacher's name. Kienpointner rereads Whorf through the lens of Wittgenstein and his turn to language use, and argues (493) that:

[...] it is not language as a system, but the use of language according to the rules of language games which connects language, thought and world view, especially if some particular usage becomes the commonly accepted norm [...] in a speech community. In the norm, possibilities of expression according to the structural system of a language are fixed and thereby reduced to a linguistic tradition reflecting certain ideological backgrounds.

Umberto Eco (Semiotics and the Philosophy of Language 14) starts out by declaring the crisis or even the death of the sign, the most basic however elusive concept of semiotics, only to undertake a large review of all different types of signs, icons and symbols and their description by important authors of the field to find a stable

5 The fact that Tractatus 5.6 is so frequently cited in language learning and translation contexts by authors who most probably did not read the Tractatus confirms Humboldt's aperçu that all understanding is at the same time notunderstanding.

Cad. Trad., Florianópolis, v. 39, no 3, p. 50-89, set-dez, 2019. 
definition of invariable signs which could legitimate meaning. Later metaphors and isotopies as defined by Greimas and discursive and narrative isotopies add a textual dimension to signs in syntagmatic chains (190), ultimately so save semiotics. In parallel to Humboldt, Eco (Semiotics and the Philosophy of Language 45) defends a dynamic nature of signs as process, not as static or absolute values. "The notion of sign as expression of equality and identity could be legitimately claimed to support a sclerotic (and ideological) notion of the subject" (ibid.) Finally, the crisis of the sign is constitutive for all signs and in the end it turns out that the process of semiosis continuously (re-)creates not only the sign but at the same time the subject who uses and is defined by signs in Eco's view (ibid.):

The sign as the locus (constantly interrogated) for the semiosic process constitutes, on the other hand, the instrument through which the subject is continuously made and unmade. The subject enters a beneficial crisis because it shares in the historical (and constitutive) crisis of the sign. The subject is constantly reshaped by the endless resegmentation of the content. In this way (even though the process of resegmentation must be activated by someone, who is probably the collectivity of subjects), the subject is spoken by language (verbal and nonverbal), by the dynamic of sign-functions rather than by the chain of signifiers. As subjects, we are what the shape of the world produced by signs makes us become.

Perhaps we are, somewhere, the deep impulse which generates semiosis. And yet we recognise ourselves only as semiosis in progress, signifying systems and communicational processes.

Izidoro Blikstein who translated Saussure, Jakobson, Dubois, Barthes and Eco's semiotic works into Brazilian Portuguese later exposed an interesting own approach to expand the traditional semiotic triangle of sign, signification and (extralinguistic) object. 
He defends that not only after Saussure's signifiant et signifié but even in medieval discussions of signs, most authors only discuss the connection between signs and their mental representation (meaning), without looking at the relationship of both with extralinguistic reality. Blikstein (81) exposes a circular schematic where social praxis creates traits of identification and differentiation which receive positive or negative values and turn into "semantic forms" (this is the moment of semiosis for Blikstein) creating isotopic corridors and stereotypes (socialised as perceptive filters) which in turn relate to sign usage and referential meaning, thus returning to the initial point of the circle that fabricates reality in our mind. In the words of Blikstein (80, our translation):

\section{[...] in this interaction language/praxis a circular reiteration installs itself which, in principle, cannot be broken: praxis creates the stereotypes on which the language depends and these, in turn, materialize and reiterate praxis.}

In the tradition of Wilhelm v. Humboldt, E. Sapir and B. Whorf, A. Martinet, R. Barthes, and many others, Blikstein believes that the subject and language model each other in an interdependent process within a dialectical semiotic system where there are no monocausal or rigid explanations. This operates as a network of multiple influences that together form a more or less stable platform, but on the basis of necessarily dynamic elements. However, only this flexibility and capacity for continuous adaptation guarantee the possibility and functionality of the semiotic process.

This approach has several advantages: 1) it overcomes the impasse of the closed semiotic triangle which cannot define "sign" without logical circularity and does not explain its access to the real world; 2) it solves the problem of meaning, ideological traits, isotopic corridors and stereotypes, erected by praxis and based on the existential experience of the human condition. There are several parallels with the Humboldtian view (intertwining on an 
individual and collective level, dialogical construction, no fixed meaning), but also significant differences. Consistent with his approach of placing the central step of the semiotic process outside the semiotic triangle, Blikstein assumes the existence of pre- or non-linguistic cognitions and meanings, still unconnected with any verbal concept. Evidently there are (as yet) uncoded cognitive impressions, such as a smell or sound, a piece of music, etc. They can spontaneously evoke memories and emotions that are vivid and manifest and nevertheless hard to express. Another example includes cases where one has a clear idea of something, but the word does not come to mind, it is "on the tip of the tongue". This kind of non-verbal "meaning" would be similar to animal cognition, or "pure vision", not yet conventionalised by social praxis (in Blikstein's model the formative organ of thought), in the example of Blikstein represented by Kaspar Hauser, the famous case of late and incomplete language acquisition that did not permit a satisfactory "fabrication of reality".

\section{From poststructuralism to postcolonial theory}

Post-structuralist theories and deconstructivism, as mentioned above, are converging in several key issues with the Humboldtian view even if they start out from different presuppositions. One is the option for an empirically construed meaning and not a "transcendental signified", "primum signatum", "primum cognitum" or logos (Derrida 20). Barthes' famous essay "The Death of the Author" sums up the shift towards the reader in the process of creation of meaning (148): "The reader is the space on which all the quotations that make up a writing are inscribed without any of them being lost; a text's unity lies not in its origin but in its destination". Michel Foucault adds an important dimension that connects post-modern theories to post-colonial discussion of language and asymmetric relations (52f): “[...] discourse is not simply that which translates struggles or systems of domination, 
but is the thing for which and by which there is struggle, discourse is the power which is to be seized."

Decades later, Niranjana (6) sets out to put Foucault's approach into practice:

The rethinking of translation becomes an important task in a context where it has been used since the European Enlightenment to underwrite practices of subjectification, especially for colonized peoples. Such a rethinking task of great urgency for a post-colonial theory attempting to make sense of "subjects" already living "in translation," imaged and re-imaged by colonial ways of seeing seeks to reclaim the notion of translation by deconstructing it and reinscribing its potential as a strategy of resistance.

The author warns us not to easily instantiate hegemonial views and/or conceptual prisons when looking at otherness and to maintain critical thought and analysis (186) because "[...] it seems more urgent than ever to be aware of the instability of the 'original', which can be meticulously uncovered through the practice of translation." Susan Bassnett and Harish Trivedi (2) state that translation "rarely, if ever, involves a relationship of equality between texts, authors or systems". The same may be said for interpreting situations. Theo Hermans resumes the postcolonial approach as follows:

Both postcolonial and gender-oriented approaches have in common with poststructuralism a mistrust of the beguiling rhetoric of hegemonic discourses and an unwillingness to continue to think in essentialist or binary terms. But postcolonial theory puts the emphasis on the impact and significance of translation in a context of political, military, economic and cultural power differentials. 
Hermans defines postcolonial research as interested in analysing cultural appropriation or domination by means of (translated) discourse. According to this view, translation "becomes entangled in a web of complicity. Postcolonial studies question the morality of this complicity and celebrate those instances where translations appear to resist domination" (ibid.).

\section{Conflicting Narratives}

As the different theoretical approaches above have shown, language is the means we have to see, think and communicate the world and it has an eminently creative potential. We need to create sense and we use words and sequences of words to do so. The collective and individual dimension are interdependent. They create at the same time collective and individual identity. Language is the basis for all human institutions, be they material or immaterial. Our points of view are based on the view we have from the point we are standing and the time we are looking. This implies that other individuals or collectives who stand at different points or look at different times will have different views. By definition, language use is poetic (poesis). It creates us, our views and our world. As Humboldt (91) states, it makes "infinite employment of finite means". This includes at the same time the micro and macro structures in language, phonology, syntax and semantics as well as discourse. Frege (71) saw this principle (later developed as Generative Grammatic by Chomsky ${ }^{6}$ ) at work when he says "One should not forget that different sentences may express the same thought. [...] Language has means to let this or that part of the thought appear as subject" and cites two examples of the same idea where the subject is turned into the

${ }^{6}$ See Baumann and Gipper (Individuelle und universelle) on Chomsky's use of Humboldt's writings and language universals in the Humboldtian theory of language. See Heydrich on theoretical overlap in Humboldt and Frege.

Cad. Trad., Florianópolis, v. 39, no 3, p. 50-89, set-dez, 2019. 
object by a syntactic transformation using another verb with different regency. Substitutions and transformations can also be operated on the semantic level, still referring to the same idea but with different nuances or details. The same fact can be referred to from different angles and be part of a different discourse. Humboldt's paradox holds true on the level of codification and decodification. The same text can have infinite interpretations and translations that are legitimate renderings. Even one and the same reader who reads a text at different moments will necessarily have differing interpretations, either reinterpreting or elaborating more on their previous interpretation. Heraclitus of Ephesus' famous

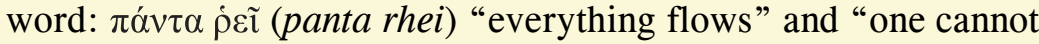
enter the same river twice" also applies to texts. Eco on the one hand defends unlimited semiosis, and writes on the limits of interpretation where (The limits of interpretation 23) he uses the double metaphor of the world as a text and the text as a world, and therefore, to interpret means at the same time "react to the text of the world or to the world of a text by producing other texts". However, while it is always possible to create new interpretations about existing texts, as Eco demonstrates, unlimited semiosis does not mean that any interpretation is legitimated by the text.

At the same time, the possibility and inevitability of differing interpretations creates several dialectic processes. Leontiev based on Bakhtin and Vygotsky and in alignment with Humboldt and Blikstein describes communication as the struggle of individual sense for collective meaning, sense as internalised meaning and meaning as externalised sense. At the convergence of language philosophy, semiotic theories, psychological theory of human activity, applied linguistics (such as speech act theory and discourse analysis), poststructuralist and postcolonial theories, we can assume that our views on world on different levels are based on and construed dialectically by constitutive narratives (including herein science as such) that may be congruent or concurring, solidary or conflicting at varying degrees. Baker (10) in her study Translation and Conflict elaborates: 
Scientific theories and reports are narratives in the sense that they are ultimately "stories" that have a beginning, middle and end. More specifically, narrative does much of the work that we identify with "objective" scientific discourse. It is narrativity that turns the continuous flow of experience into a set of delineated categories that can be processed in various ways, and this [...] includes scientific categories.

Her interest aligned with postcolonial theories is to analyse to what extent and in which ways "translators and interpreters participate in both circulating and resisting the narratives that turn the whos of our time into the its whose suffering is either justifiable or at best simply 'regrettable' [...]" (Baker, Translation and Conflict 14). Baker's book caused more of an impact due to the fact that most of the examples were extracted from ongoing conflicts of the western world with Arabic nations, raising accusations of antisemitism even within the academic world. The author defends in continuation of Niranjana and Tymoczko that translation is almost always present in the complex and elaborate cycles of power and resistance (Baker, Translation and Conflict 25). Baker's view on power differentials in translation is not only pessimistic, as she states, we should not forget that translation is also a means and an opportunity for "contesting and undermining this very domination" (ibid.). Nevertheless, according to the author, many translators and interpreters

refuse to reflect on the implications of their choices almost as a matter of principle, opting instead to translate any and all narratives in a detached manner, thus helping to circulate and promote them irrespective of their own narrative location. (id. 26)

Others contest dominant narratives and call for critical reflection and examination. However: "Neither can escape being firmly 
embedded in a series of narratives that define who they are and how they act in the world" (ibid.).

Baker (Translation and Conflict 28-49) then distinguishes four types of narratives (ontological, public, conceptual and metanarratives), based on Somers (Narrativity, Narrative Identity, The Narrative Construction) and Somers and Gibson. Ontological narratives describe the individual, collective or institutional self and can be based on stability, or include progressive or regressive dynamics (e.g., infinite scientific progress in technocratic societies, or cultural decadence as in Oswald Spengler's Decline of the Western Civilization). Conflicting ontological narratives account for many cultural differences. And Baker (Translation and Conflict 31) states that "Interpreters who work with refugees and asylum seekers witness this type of conflict between the migrants' personal stories and the narratives of the receiving culture in very vivid terms". Public narratives include literature, conceptual narratives or disciplinary narratives and are constitutive for technical and scientific fields and meta- or master-narratives which contain aspects such as nature vs culture, and enlightenment, for example. In chapter 4, Baker (Translation and Conflict 50ff) describes features of narratives, such as temporality, relationality, causal emplotment and selective appropriation. Chapter 5 discusses to what extent narratives are particular or generic, normative or canonical and the potential for breaching such narratives. Baker uses Goffman's concept of frames and framing that always implies both establishing meaningful references and ambiguity of selective interpretation or appropriation of such frames.

As both storytellers and audience, we make decisions on the basis of what Fisher calls good reasons, but what we consider good reasons is determined by our history, culture, experience of the world, and ultimately the stories we come to believe about the world(s) in which we live. (Baker 142) 
Directly aligned with Humboldt and his philosophy of language, Leontiev and his psychological theory of mind and human activity and Blikstein and his semiotic model, although coming from a different theoretical approach, Baker (Translation and Conflict 143) believes that "all forms of human communication function to influence the hearts and minds of others" and points out that "good reasons" are linked to and based on values that are adopted by social praxis in the context of the constitutive narratives of a culture.

When opting for adherence to specific narratives or frames, translators and interpreters face ethical choices:

to reproduce existing ideologies as encoded in the narratives elaborated in the text or utterance, or to dissociate themselves from those ideologies, if necessary by refusing to translate the text or interpret in a particular context at all" (Baker, Translation and Conflict 105).

Again, Baker stresses that this is not only a burdening responsibility, but also a chance of reframing certain narratives (ibid.):

The assumption throughout is that translators and interpreters are not merely passive receivers of assignments from others; many initiate their own translation projects and actively select texts and volunteer for interpreting tasks that contribute to the elaboration of particular narratives. Neither are they detached, unaccountable professionals whose involvement begins and ends with the delivery of a linguistic product. Like any other group in society, translators and interpreters are responsible for the texts and utterances they produce. Consciously or otherwise, they translate texts and utterances that participate in creating, negotiating and contesting social reality. 
As cultural and linguistic mediators, translators and interpreters have to make differing and not rarely conflicting narratives based on distant or opposed points of view (Humboldt's Weltansicht), intelligible for the respective target audience(s). "In other words, they actively attempt to narrow the gap between the personal and collective or institutional narrative", (Baker, Translation and Conflict 31), despite being instructed explicitly to translate exclusively and exactly what has been said (or written). As Bahadir (Moving In-Between 806) states, again aligned with Humboldt:

Any conversation, whether between two or three parties, is based on a pragmatic basis of common action, not 'real' comprehension. All the persons in interaction create the communication situation, what then looks as if they would understand each other. Whenever they hear, see, perceive something, they re-shape it in order to be able to comprehend.

Baraldi (32) defines that

[...] language mediation includes systematic modified renditions and non-renditions of interlocutors' utterances as ways of coordinating interaction. These modified renditions and non-renditions may be seen as production of narratives and cultural assumptions.

In the next section we will see that the interpreter's task is exactly to make sure this common communicative action is possible, and not simply to "translate what has been said". The need to be able to access and at least partially share conflicting narratives is therefore constitutive for interpreter identity. 


\section{How does an interpreter operate?}

Recent publications in the field of Interpreting Studies have amplified the view on interpreter's actuation in several senses. Not only new areas like Community Interpreting (often related to migration), but also interpreting in more challenging fields than traditional conference interpreting, such as sign language interpreting, healthcare interpreting or interpreting in war zones. They have added considerably to the comprehension of various aspects of interpreting itself and cast focus on different skills, interpreter training, interpreter ethics and interpreter identity. At the beginning of the 'cultural turn' in translations studies, Snell-Hornby (13) identifies a conflict between globalism and tribalism, a cultural identity marked by a "globalised world governed by "universalizing markets' and a tribalised world torn apart by 'parochial hatreds"'.

Bahadır (Moving In-Between) in her article looks at interpreters as ethnographers ${ }^{7}$ and interpreting researchers as anthropologists, both are affected by the Geertzian dilemma of etic (outside perspective) and emic (inside perspective) - see Geertz - (Bahadir, Moving In-Between 807):

This involves a pondering how to observe, to comprehend, to describe (i.e. name), to evaluate and then to mediate (i.e. interpret) as an 'I' (i.e. a person-in-cultures), provisionally designated researcher, the Others (i.e. persons-in-cultures), provisionally named 'research objects.' Interpreters, too, face the question of whether and how they have the capacity/

\footnotetext{
${ }^{7}$ Hensley also uses the metaphor of interpreter as bicultural/bilingual ethnographer describing a setting where she initially had been contracted as interpreter in a Deaf Studies field research but ended up switching between the roles of researcher and interpreter. A different shift of frame is analyzed by Takimoto and Koshiba in a business negotiation between US and Japanese participants where one of the Japanese participants starts to talk in English, bypassing and at the same time inverting the interpreter's position who at this point had to interpret back into Japanese in order not to exclude the remaining Japanese participants.
}

Cad. Trad., Florianópolis, v. 39, no 3, p. 50-89, set-dez, 2019. 
right/responsibility to observe, to comprehend, to describe (i.e. name), to evaluate and then to mediate (i.e. interpret) as an 'I' (i.e. a person-in-cultures), provisionally designated interpreter, (between) the Others (i.e. persons-in-cultures), provisionally named clients, patients, migrants, doctors, lawyers, social workers, psychiatrists, etc."

The author states that it is important to step out of "the sphere where transparency, invisibility, neutrality, and along with these ideals, a kind of 'dehumanization' represent the professional standards for both (community) interpreting and research on (community) interpreting." (id. 813). Dušan Tellinger sustains that a "traditional view of interpreters as neutral language mediators and as a "translating-machine" does not fit reality anymore." (Tellinger 53).

This refers at the same time to a more complex view on interpreting skills and on interpreter identity. Interpreters are affected by the hermeneutical and deontological complexity of the task. They are involved as receiving and emitting participants and as such are affected by the emic end:

As soon as they 'own' the target culture (just like in the case of their first culture), they are manipulated and determined in their behavior and way of thinking by this new culture as well. As a consequence, the ethnographer has to cope with multiple patterns of perception and evaluation, even with flexible loyalties." (Bahadır, Moving In-Between 807)

And at the same time, they should stay in the etic realm, being in charge of the management of the intercultural communication taking place, responsible for the possibility of the partial understanding described above. Yagi and Kleinberg (629) also rely on the ethnographer's perspective on negotiating and leveraging cultural identity and introduce the concept of "boundary work" by 
the interpreter and define "boundary spanning as a process shaped through the interplay of the contextual issues that make a boundary problematic". Baraldi (27) states:

The mediator's coordination should be successful in managing the lack of fit between different cultural forms, creating the conditions for cross-cultural adaptation (Kim 2001) and enhancing the participants' display of their cultural identities $[\ldots]$.

Metzger had already questioned the possibility of a passive neutrality of interpreters of sign languages, using a different theoretical background but the same arguments: a) sign language interpreters are part of the deaf community (otherwise they would not be able to achieve linguistic and cultural competence) and as such they will almost inevitably tend to defend the still largely excluded deaf minority's interest, and b) due to the great linguistic and cultural difference, they have to actively control the form this communication takes place to make at least a partial comprehension possible and by this they will end up teaching the hearing participants how to look at and communicate with the deaf minority. In the same sense, Nadja Grbić (200) who analyses the emerging system of sign language interpreters in the Austrian province of Styria describes the "strong emotional bonds with the deaf person(s) for whom they worked." This is practically inevitable as in many cases the interpreter lives in the same community as their clients and is thus related to them long before the interpreting event. A 'failure' to advocate their clients' fair interest might not only create an impact on their future professional activities but may also affect the interpreter's social relationships.

The groundbreaking study that demonstrated how the triadic interaction of a Swedish speaking Police inspector, a Russianspeaking defendant and their interpreter is in a Bakhtinian way cocreating understanding and common ground, was Cecilia Wadensjö's 
PHD thesis from 1992 and the publication of "Interpreting as Interaction" as a book in 1998. Jemina Napier (409) comes to the same conclusion: "it can be said that interaction participants cooperate with one another to navigate discourse, and co-construct meaning". Roy (A Sociolinguistic Analysis, Interpreting as a Discourse) shows the active role of interpreters for turn-taking management and for maintaining the flow of communication in interpreting between deaf and hearing participants.

In a more general approach, Sandra B. Hale (102-119) differentiates between five roles that may be adopted by a community interpreter: advocate for the minority language speaker (including cultural brokerage), advocate for the institution or service provider, gatekeeper who filters and edits information, facilitator of communication and uninvolved renderer of utterances from both sides. Davitti (37) in her analysis of interpreter mediated TeacherParent communication shows that gaze is a central element for interpreters to handle important communicational functions based on Goffman (227) who distinguishes the dialogical roles of author, animator, responder, reporter and recapitulator. Nakane analyses how interpreters switch between these roles in concrete police interpreting situations. Finally, as formulated by Davitti (24):

Each mediated face-to-face encounter is unique, and its outcome is the result of a subtle combination and balancing out of strategies adopted and choices made by the interpreter and by the participants involved in a constant process of interactional negotiation.

Bahadir (The task of the interpreter 124) also agrees on the impossibility of neutrality and adds:

As there can be no neutral part in mis/communication and as there is no objective way of perceiving, analyzing, and processing information and emotions, professional 
interpreters must position themselves. Numerous examples from situations where interpreters act as intermediaries between the dominating and violating agents of societies/ states and migrants, refugees, and members of minoritized and oppressed communities illustrate the challenges involved in simultaneously representing and mediating the speech of the Other.

As a minimum condition for professionalism she demands that "interpreters must be sensitised and trained to cope with the dangers and opportunities of their in-between position and of their third-party status" (ibid.).

Bahadır (Moving In-Between 815) finishes her investigation claiming for a change of view as follows ${ }^{8}$ :

Since the actually experienced interpreting situation is so complex and loaded with ethical dilemmas on different levels, there is a striving for best possible abstraction of the activity and for simplification of the professional profile. In contrast to this tendency, I expect from a code of ethics for professional community (and any other kinds of) interpreters to 'restore' the difficulty and the complexity of interpreting, to foreground the necessity of an awareness of the 'vulnerability' of the project of translation/interpretation.

Ruano (14) adds more concrete demands:

If neutrality is impossible but expected, the delimitation, both theoretically and through situated practice, of the legitimate space where intervenient translators may operate without compromising the impartiality requested of them seems to be an urgent need.

${ }^{8}$ In the same sense also see Angelelli (Revisiting the Interpreter's Role, Validating Professional Standards and Codes). 


\section{Interpreter identity}

Michael Cronin in his book Translation and Identity (Cronin 9) uses the socio-cultural definition of cosmopolitanism in the sense of Kant's humanistic view of all human beings as citizens of the world, as "complexity of a poly-identity" rather than single, allencompassing identities based on a closed set of variables.

Adler (249) defines:

The multicultural person, therefore, is not simply the person who is sensitive to many different cultures. Rather, he is a person who is always in the process of becoming a part of and apart from a given cultural context. He is very much a formative being, resilient, changing, and evolutionary. He has no permanent cultural character, but neither is free from the influences of culture.

Shlesinger and Jettmarová (3) justify the growing interest in interpreter identity as follows:

If there has been a growing focus on mediators and their social contexts, it is perhaps more evident in the field of interpreting than that of written translation. After all, the interpreter's situation is there, immediately visible for all to see. [...] We might then posit that, for some scholars and more particularly in some fields of research, the focus has shifted from texts to mediators. Many of us are no longer stopping at the sociocultural dimensions of source and target texts. We would like to know more about who is doing the mediating.

Mona Baker, in her introduction to $A$ Companion to Translation Studies (15) declares that besides textual material the area of Translation and Interpreting Studies "has sought to incorporate 
within its remit various types of non-verbal material as well as the agents who produce translated texts and mediate oral interaction".

Edwards (197) who conducted studies on single mothers from a migration background through interpreters defends that the unreflected model of a traditional value-free view on the interpreters' role without considering cultural identity still in use can cause serious impact on data for qualitative research and may bias results severely.

Camayd-Freixas (24) confirms the affirmations about the relevance of sociolinguistic and prosodical cues for efficient interpretation made in Weininger but also points at the root of possible identity conflicts:

The interpreter must convey what is said but also how it is said, that is, the state of mind of the speaker. This is only possible by identifying morally and culturally with each speaker. Further, the interpreter's bilingual and bicultural competence provide for a high degree of cultural and historical familiarity with each speaker.

Carstensen and Dahlberg (58) go one step further and show that the inevitable and strategically important bicultural involvement of interpreters is not a side-effect but one of the pillars of efficient interpreting in certain contexts:

According to the interviews that we have conducted, it is evident that the emotional work of the interpreter plays an important role in the proceedings. For instance, the lawyers say that interpreters have a calming effect on their clients. [...] When the interpreters refer to such experiences, it becomes apparent that sometimes it is not possible-or even desirable-for an interpreter to hold a distance to the situation, to assume a neutral and objective position and 'just interpret'. From the interviews, it is clear that there 
is no such thing as 'just interpreting', since the context of interpreting consists of an interactive and communicative dialogue based on processes to create meaning.

Rudvin investigates the sensitive role of interpreters in community interpreting and argues that the

interpreter's cultural parameters affect his/her view of professional role and professionalism. This assumption raises the question of whether or not $\mathrm{s} / \mathrm{he}$ is also guided (consciously or unconsciously) by the host country's understanding of ethics and professionalism and whether these two potentially opposing values tend to converge over time". (Rudvin 47).

The author also observes that the interpreter's role might be heavily influenced by the needs of the institution that pays for interpreting services and suspects that it will be problematic to establish a universal code of professional ethics.

Ruano (1) insists that this fact is not only ignored by the public image and ethical codes both interpreters and their clients adhere to, but also shows that this incoherence bears a high potential for professional and personal conflicts. This "state of affairs" of a supposedly invisible and neutral interpreter creates a dangerous double bind:

Existing deontology seems to mould invisible beings who are annulled or disappear to unobtrusively give a voice to other persons or texts. Nevertheless, in situations marked by conflict and asymmetry, these seemingly indisputable values prove to be not only scarcely self-explanatory but also paradoxical, and indeed are very often the source of complex ethical dilemmas for professionals who perform an essentially interventionist task. 
The author states a profound identity crisis due to "ambivalent and uncomfortable feeling of insecurity and split loyalties partly deriving from the contradictory expectations, demands and needs of the various agents in the interpreted encounter" (id. 2). Ruano (1011) defends that this not only implies conflicts ethically speaking but even puts neutrality in contradiction with accuracy:

In fact, inasmuch as translation entails a refracted reception of alien idiosyncrasies, and to the extent that the ensuing relocation of meaning is inevitably influenced by the dominant ideologies, established identity constructions, and accepted social discourses and narratives prevailing in the target context, the renderings resulting from literal translation, due to their lack of convergence with reigning expectations or values, might be perceived as blunt, weird or exotic, and thus reinforce negative perceptions of the foreign culture as radically Other. [...] If translators and interpreters are prevented from using their knowledge and abilities to explain differences where equivalence is not an outright transaction, they are somehow forced into a clandestine status of involuntary offenders, obliged to operate on the knife-edge of (un)lawfulness.

In other words, while translators were depreciated as traitors (in relation to textual fidelity - an overcome category in translation studies), interpreters can come close to a situation of being double agents (in relation to loyalty - a more modern concept in the field): useful for both sides but living under constant pressure, internally torn and hiding away part of their actuation while running a high personal risk.

Li, Tian and Huang study ethics, identity and ideology of interpreters during the Sino-Japanese War (1937-45) where Japanese troops occupied parts of China and used interpreters to communicate with the local population. They analyse situations where professional ethics, situational ethics and cultural identity 
are conflicting due to the multicultural narrative conflict they live in and the situational ethics of saving lives (including their own) or their country overrules professional ethics.

There are many situations in which interpreters experience conflict and uncertainty over what constitutes their primary duty and what counts as ethical behaviour. In such instances, they must determine, sometimes in a matter of seconds, whether their obligation should be oriented to their profession, to the person or institution paying their fee, to a member of their own culture, religion, gender or ethnic group, or to a particular country or set of principles. Any one of these factors may make an interpreter decide that it is ethically permissible to break with professional ethics. (Li, Tian and Huang 171)

Another example are interpreters used by allied troops in the Afghanistan and Iraq wars who were later denied protection or citizenship that would save them from revenge by the other side, based on the allegation that they are a threat to national security, just because of their cultural identity that was the condition for completing their job successfully in the first place ${ }^{9}$.

In terms of professional roles, Ruano (14) is suggesting a solution:

The strict, but ultimately insufficiently detailed discourse of regulatory instruments such as codes of ethics, focusing mainly on what translators and interpreters cannot do, can be replaced by or completed with more comprehensive explanations of what translators and interpreters need to do,

\footnotetext{
$9 \quad$ See: < https://www.theguardian.com/commentisfree/2013/sep/27/afghaninterpreter-visas-janis-shinwari > or < https:/www.alaraby.co.uk/english/ indepth/2018/4/12/the-iraqi-translators-betrayed-by-the-united-states $>, \quad$ and $<$ https://www.militarytimes.com/news/your-military/2019/04/18/iraqi-translatorrisked-his-life-on-raids-with-us-troops-now-hes-fighting-for-citizenship/ $>$.
} 
and even of what else they could legitimately do, in the interest of intercultural communication broadly understood as a guiding principle of our multicultural age.

Many of the scholarly articles quoted here were elaborated by professional interpreters, their suggestion is clear. We should value their double agency in mediation of (potentially) conflicting narratives through their capacities of approaching narratives discoursively, producing at least a chance of successful intercultural communication, without suffering conflicts in relation to their professional, cultural or personal identity. The analysis of interpreter identity itself is still in its beginnings, there are very few academic studies on this subject. Therefore, we finish this analysis on narrativity as approach to interpreter identity by looking at literary texts with interpreters as main characters. Ruano (2) analyses Suki Kim's novel “The Interpreter" and its main character Suzy Park as testimony for the professional conflict:

The rigid requirements pending upon her-Accuracy, Neutrality, etc.-clash with her painful perception of very real conflicts and gaps which cannot be encompassed by such abstract vocabularies: the precariousness of immigrant life, often taken advantage of by aggressive lawyers; the misunderstandings caused by culturally-stereotypical replies, aggravating the already evident power differentials. Thus, the sense of duty which she feels compelled to honour often melts with sentiments of desolation and helplessness, but also of disenfranchisement, vulnerability and guilt: the impression - a growing one in the discipline of translation and interpreting studies [...] - that deontology in its current form may be at odds with ethics. 
Ruano does not look at the identity conflict of a seemingly well assimilated second-generation Korean immigrant ${ }^{10}$ living in New York who at the same time becomes more conscious about power differentials in her rendering of court-room discourse and slowly changes her "neutral" attitude towards comprehension and active participation to produce more balanced results while she discovers step by step that her parents (apparently victim of an assault of their grocery store) had been murdered as revenge. This was because they had collaborated with immigration services for decades turning in illegal Korean immigrants to grant their own legal status. She has to break down several walls of silence in different contexts (close family, workplace, immigrant community, police) until she finally discovers the full truth and regains access to her own history and cultural heritage.

A joint research project has foregrounded translators and interpreters as protagonists in international narrative fiction. Ingrid Kurz and Klaus Kaindl from the Center of Translation Studies at the University of Vienna have invited colleagues to write short texts about how interpreters and translators are portrayed in fiction. The three volumes' titles already indicate the results: 1. Wortklauber, Sinnverdreher, Brückenbauer? DolmetscherInnen und ÜbersetzerInnen als literarische Geschöpfe (2005) [translation: Quibblers, Meaning-Twisters, Bridge Builders? Interpreters and Translators as Literary Creatures]; 2. Helfer, Verräter, Gaukler? - Das Rollenbild von TranslatorInnen im Spiegel der Literatur (2008) [translation: Helpers, Traitors, Jugglers? - The Role Image of Translators/Interpreters in Literature]; 3. Machtlos, selbstlos, meinungslos? - Interdisziplinäre Analysen von ÜbersetzerInnen und DolmetscherInnen in belletristischen Werken (2010) [translation: Powerless, Selfless, Opinionless? - Interdisciplinary Analyses of Translators and Interpreters in Fiction]. Andres (2008) has dealt with this topic most extensively under the title: Dolmetscher als

${ }^{10}$ See Heidermann on migrant literature and the construction of identity in a new language.

Cad. Trad., Florianópolis, v. 39, nº 3, p. 50-89, set-dez, 2019. 
literarische Figuren. Von Identitätsverlust, Dilettantismus und Verrat [translation: Interpreters as Literary Characters. About Loss of Identity, Dilettantism and Betrayal].

Some brief examples: In her novel "The Interpreter", former interpreter Suzanne Glass depicts Dominique, daughter of a holocaust survivor, who sacrifices both her career and her relationship revealing a professional secret of impact. Also initially a translator and interpreter, Javier Marías (whose father suffered persecution by the Spanish regime under Franco) mainly describes the creative power of language in his novel "A Heart So White" where (overheard) words create attitudes and fates that are revealed by intelligent use of interpretation to the point at which an interpreter induces through slight interventions in his interpreting high profile political actors to actually say what they think. Hungarian translator Ágnes Gergely (whose father died in a Nazi extermination camp), portrays the permanent identity conflict of the interpreter that exceeds her professional role. Lastly, there is the Sudanese interpreter Daoud Hari's autobiographical narrative about how he risked his life, was imprisoned and tortured as a spy when facilitating access to information on the atrocious Darfur genocide to international journalists and NGOs. To be able to interpret in Chadian refugee camps and grant access to foreign medical aid there he had to act as a real double agent and create a Chadian identity as Suleyman Abakar Moussa, because the government of Chad only accepted Chadian interpreters in refugee camps. Despite taking the interpreters' identity conflicts in each sense to an extreme, Daoud managed to preserve his prevalent identity of approaching conflicting narratives within his continent and abroad. Although fortunately most interpreters are not exposed to such extreme situations, their identity is always constituted within the field of tension between diverging narratives and they experience more pressure as conflict and power differentials enter the field. 


\section{References}

Adler, P. S. "Beyond Cultural Identity: Reflections on Cultural and Multicultural Man”. In: Weaver, G. (Ed). Culture, Communication and Conflict: Readings in Intercultural Communication. Needham Heights: Simon and Schuster Custom Publishing, 1994.

Andres, D. Dolmetscher als literarische Figuren. Von Identitätsverlust, Dilettantismus und Verrat. Munich: Peter Lang, 2008.

Angelelli, C. Revisiting the Interpreter's Role. Amsterdam/Philadelphia: John Benjamins, 2004.

Angelelli, C. "Validating Professional Standards and Codes: Challenges and Opportunities”. Intepreting 8.2, 2006: 175-193

Baker, M. Routledge encyclopedia of translation studies. London/New York: Routledge, 2001.

Baker, M. Translation and Conflict: A Narrative Account. London/New York: Routledge, 2006.

Baker, M. "The Changing Landscape of Translation and Interpreting Studies". In: Bermann, S., and Porter, C. A Companion to Translation Studies. Hoboken: Wiley \& Sons, 2014.

Bahadir, Ş. "Moving In-Between: The Interpreter as Ethnographer and the Interpreting-Researcher as Anthropologist”. Meta, 49.4 (2004): p. 805-821.

Bahadir, S.. "The task of the interpreter in the struggle of the other for empowerment: Mythical utopia or sine qua non of professionalism?". Translation and Interpreting Studies. The Journal of the American Translation and Interpreting Studies Association 5.1 (2010): 124-139. 
Barthes, R. "The Death of the Author". Image, Music, Text. Trans. S. Heath. London: Fontana, 1977.

Bassnett, S. and Trivedi, H. Post-colonial Translation. Theory and Practice. London: Routledge, 1999.

Baraldi, C. “An Interactional Perspective on Interpreting as Mediation”. Lingue Culture Mediazione/Language Cultures Mediation 1-2 (2014): 17-36.

Baumann, H. H. "Die generative Grammatik um Wilhelm von Humboldt". Poetica 4 (1971): 1-12

Benjamin, W. "The Task of the Translator". Illuminations. Ed. Hannah Arendt. Trans. Harry Zohn. New York: Schocken Books, 1969.

Blikstein, I. Kaspar Hauser ou a fabricação da realidade. São Paulo: Cultrix, 1997.

Camayd-Freixas, E. "Court Interpreter Ethics and the Role of Professional Organizations". In: Schäffner, C; Kredens, K., and Fowler, I. Interpreting in a Changing Landscape. Amsterdam/Philadelphia: John Benjamins, 2013.

Carstensen, G. and Dahlberg, L. "Court Interpreting as Emotional Work: A Pilot Study in Swedish Law Courts". NoFo 14 (2017): 45-64.

Cronin, M. Translation and Identity. New York: Routledge, 2006.

Davitti, E. Dialogue Interpreting as Intercultural Mediation Integrating Talk and Gaze in the Analysis of Mediated Parent-Teacher Meetings. PHD thesis. University of Manchester, 2012.

Derrida, J. Of Grammatology. Trans. Gayatri Spivak. Baltimore: Johns Hopkins University Press, 1976.

Eco, U. Semiotics and the Philosophy of Language. Bloomington: Indiana University Press, 1986. 
Eco, U. The limits of interpretation. Bloomington: Indiana University Press, 1990.

Edwards, R. "A critical examination of the use of interpreters in the qualitative research process”. Journal of Ethnic and Migration Studies 24.1 (1998): 197-208.

Farahani, V. M. and Farahani, N. M. "How interpreters tackle with cultural gaps in interpretation process: A descriptive study". International Journal of Research Studies in Education 6.4 (2017): 3-14.

Foucault, M. "The Order of Discourse". In: Young, R. (Ed) Untying the text: A Post-Structuralist Reader. Trans. Ian McLeod. Boston: Routledge \& Kegan Paul, 1981.

Hale, S. B. "Controversies over the Role of the Court Interpreter". In: ValeroGarcés, C., and Martin, A. (Eds). Crossing Borders in Community Interpreting: Definitions and Dilemmas. Amsterdam: John Benjamins, 2008.

Hari, D. The Translator. London: Penguin Books, 2008.

Jones, R. Conference interpreting explained. Northampton: Saint Jerome, 2002.

Geertz, C. "Thick Description: Toward an Interpretive Theory of Culture". The Interpretation of Cultures. New York: Basic Books, 1973.

Gergely, A. Die Dolmetscherin. Trans. H. Skretski, Berlin: Volk und Welt, 1983.

Gipper, H. Gibt es ein sprachliches Relativitätsprinzip? Überlegungen zur SapirWhorf-Hypothese. Frankfurt: Suhrkamp, 1972.

Gipper, H. "Individuelle und universelle Züge der Sprachen in der Sich Wilhelm von Humbodts". In: Hammacher, K. (Ed). Universalismus und Wissenschaft im Werk und Wirken der Brüder Humboldt. Frankfurt: Klostermann, 1974.

Grbić, N. "From 10-minute wedding ceremonies to three-week spa treatment programs. Reconstructing the system of sign language interpreting in Styria". In: 
Pym, A.; Shlesinger, M., and Jettmarová, Z. Sociocultural Aspects of Translating and Interpreting. Amsterdam, John Benjamins Publishing Company, 2006.

Heidermann, W. "Literatura Chamisso, a literatura alemã proposta por nãoalemães". Revista Landa 5.1 (2016): 604-618.

Hensley, J. "Blurred Boundaries: Interpreters as Researchers in Cross-Cultural Settings". Journal of Interpretation 25.1 (2016): 1-19.

Hermans, T. "Postcolonial Theory". Theories of Translation and Interpreting. Ed. ARTIS (Advancing Research in Translation \& Interpreting Studies). University of Manchester, University of Edinburgh, University College London and Hong Kong Baptist University, 2005. < https://artisinitiative.org/onlinecourse/module-theories-of-translation-interpreting/module-2-unit-1-disciplinaryobjectives-theo-hermans/chapter-9-postcolonial-theory/ > .

Heydrich, W. Dier Vermessung der Sprache: Humboldt und Frege. Vortrag der Gesellschaft für die Deutsche Sprache am 19.5.2009 an der Ruhr Universität Bochum, 2009. <http://www.ruhr-uni-bochum.de/germ-ling/doz/>.

Humboldt, W. On Language, On the Diversity of Human Language Construction and its Influence on the Mental Development of the Human Species. Trans. P. Heath. Ed. Michael Losonsky. Cambridge: Cambridge University Press, 1999.

Kaindl, K. and Kurz, I. (Eds.) Helfer, Verräter, Gaukler? - Das Rollenbild von TranslatorInnen im Spiegel der Literatur. Vienna: LIT Verlag, 2008.

Kaindl, K. and Kurz, I. (Eds.) ed. Machtlos, selbstlos, meinungslos? Interdisziplinäre Analysen von ÜbersetzerInnen und DolmetscheriInnen in belletristischen Werken. Vienna: LIT Verlag, 2010.

Kienpointner, M. Whorf and Wittgenstein. "Language, World View and Argumentation". Argumentation 10 (1996): 475-494.

Kim, S. The Interpreter. New York: Picador, 2003. 
Kurz, I. and Kaindl, K. (Eds.) Wortklauber, Sinnverdreher, Brückenbauer? DolmesterscherInnen und ÜbersetzerInnen als literarische Geschöpfe. Vienna: LIT Verlag, 2005.

Leontiev, A. N. Problems of the development of the mind. Moscow: Progress, 1981.

Li, P., Tian, C. and Huang, Z. "Ethics, identity and ideology: A study of the interpreters in the War of Resistance against Japanese Aggression (1937-1945)". Linguistica Antverpiensia, New Series: Themes inTranslation Studies 15 (2016): 162-185

Marías, J. A Heart so White. Trans. Margaret Jull Costa. London: Penguin Books, 2012.

Meschonnic, H. Poétique du traduire. Paris: Verdier, 1999.

Metzger, M. Sign Language Interpreting: Deconstructing the myth of neutrality. Washington: Gallaudet University Press, 1999.

Nakane, I. "The Myth of an 'Invisible Mediator': Ans Australian Case Study of English-Japanese Police Interpreting”. PORTAL - Journal of Multidisciplinary International Studies 6.1 (2009): 1-16

Napier, J. "Cooperation in Interpreter-Mediated Monologic Talk". Discourse \& Communication 1.4 (2007): 407-432.

Niranjana, T. Siting Translation: History, Post-Structuralism, and the Colonial Context. California: University of California Press, 1992.

Nolan, J. Interpretation. Techniques and Exercises. Clevedon: Multilingual Matters, 2005.

Pajević, M. "Thinking Language: Wilhelm von Humboldt Now. Introduction". Forum for Modern Language Studies 53.1 (2017): 1-6. 
Pajević, M. "Humboldt's Thinking Language: Poetics and Politics". Forum for Modern Language Studies 53.1 (2017): 95-107.

Phillips, G. A. "Ludwig Wittgenstein: A Philosophical Theory of Language Acquisition and Use". Word, 27.1-3 (1971): 139-157.

Reiss, K. Translation criticism - The potentials and limitations. Manchester: St. Jerome Publishing Company, 1971.

Roy, C. A Sociolinguistic Analysis of the Interpreter's Role in the Turn Exchanges of an Interpreter Event. PhD thesis. Georgetown University, 1989.

Roy, C. Interpreting as a Discourse Process. Oxford: Oxford University Press, 2000 .

Ruano, M. R. M. "From Suspicion to Collaboration: Defining New Epistemologies of Reflexive Practice for Legal Translation and Interpreting". The Journal of Specialized Translation 22 (2014): 1-20.

Rudvin, M. "Professionalism and ethics in community interpreting: The impact of individualist versus collective group identity". Interpreting 9.1 (2007): 47-69.

Sapir, E. Selected Writings. Ed. D. G. Mandelbaum. Berkeley: UCal Press, 1968.

Schleiermacher, F. "On the different methods of translating". Roy, C. The Translation Studies Reader. Trans. S. Bernofsky. New York/London: Routledge, 2007.

Shlesinger, M. and Jettmarová, Z. "Sociocultural Aspects of Translating and Interpreting”. In: Pym, A.; Shlesinger, M., and Jettmarová, Z. Sociocultural Aspects of Translating and Interpreting. Amsterdam: John Benjamins Publishing Company, 2006.

Snell-hornby, M. "Communicating in the Global Village: On Language, Translation and Cultural Identity”. In: Schäffner,C. (Org). Translation in the Global Village. Clevedon: Multilingual Matters, 2000. 
Somers, M. "Narrativity, Narrative Identity, and Social Action: Rethinking English Working-Class Formation”. Social Science History 16.4 (1992): 591-630.

Somers, M. "The Narrative Construction of Identity: A Relational and Network Approach". Theory and Society 23.5 (1994): 605-49.

Somers, M. and Gibson, G. D. "Reclaiming the Epistemological 'Other': Narrative and the Social Constitution of Identity". In: Calhoun, C. (Ed). Social Theory and the Politics of Identity. Oxford/Cambridge: Blackwell, 1994.

Stecconi, U. "Five reasons why semiotics is good for Translation Studies". In: Gambier, Y., Shlesinger, M., and Stolze, R. Doubts and directions in Translation Studies: selected contributions from the EST Congress, Lisbon 2004. Amsterdam: John Benjamins, 2007.

Takimoto, M. and Koshiba, K. "Interpreter's non-rendition behaviour and its effect on interaction: A case study of a multi-party interpreting situation". Translation \& Interpreting 1.1 (2009): 15-26.

Tellinger, D. "On Interpreter's Intercultural Awareness". Opera Slavica XXVI.2 (2016): 49-55.

Torop, P. Total'nyı̌ Perevod. Tartu: Ülikooli Kirjastus, 1995.

Tymoczko, M. "Post-colonial writing and literary translation". In: Bassnett, S., and Trivedi, H. (Ed) Post-colonial Translation. Theory and Practice. London: Routledge, 1999.

Trabant, J. "Vanishing Worldviews". Forum for Modern Language Studies 53.1 (2017): 21-34.

Wadensjö, C. Interpreting as Interaction: On dialogue interpreting in immigration hearings and medical encounters. PhD thesis. Linköping University, 1992.

Wadensjö, C. Interpreting as Interaction. London: Longman, 1998. 
Weininger, M. J. “Análise e aplicação de aspectos sociolinguísticos e prosódicos na interpretacao Libras-PB". In: Quadros, R.M., and Weininger, M.J. (Eds) Série Estudos da Língua Brasileira de Sinais (SELS) III. Florianópolis: Insular, 2014.

Whorf, B.L. Language, Thought, and Reality. Selected Writings of Benjamin Lee Whorf. Ed. J. B. Carroll. Cambridge: MIT Press, 1956.

Wittgenstein, L. Tractatus Logico-Philosophicus. Trans. C. K. Ogden. Intro. Bertrand Russell. London: Kegan Paul, Trench \& Trubner, 1922.

Yagi, N. and Kleinberg, J. "Boundary work: An interpretive ethnographic perspective on negotiating and leveraging cross-cultural identity". Journal of International Business Studies 42.5 (2011): 629-653.

Recebido em: 18/05/2019

Aceito em: 25/07/2019

Publicado em: Setembro de 2019

Werner L. Heidermann. E-mail: heidermann@gmail.com ORCID: https://orcid.org/0000-0003-3968-6460

Markus J. Weininger. E-mail: mjweininger@yahoo.de ORCID: https://orcid.org/0000-0002-9161-0343 